\title{
Strengthening and Improving the Construction of Ideological Work Team in Colleges and Universities in the New Era
}

\author{
Lechang Wang
}

Qingdao University of Science and Technology, Qingdao, 266042.

\begin{abstract}
The construction of ideological work teams in colleges and universities is the organizational guarantee for strengthening and improving the ideological work of colleges and universities in the new era, and is the key to building the frontiers of ideological work in colleges and universities. This paper elaborates on strengthening and improving the new era of colleges and universities from four aspects: strengthening the main body layout of college ideological work teams, improving the management mechanism of college ideology work teams, improving the comprehensive quality of college ideology work teams, and strengthening the construction of network ideology workers in colleges and universities. The effective path of the ideological work team construction provides a feasible suggestion for strengthening the ideological work of colleges and universities in China.
\end{abstract}

Keywords: Colleges, new era, ideology, team building.

\section{加强和改进新时代高校意识形态工作队伍建设探析}

\author{
王乐昌 \\ 青岛科技大学, 青岛, 266042
}

摘 要: 高校意识形态工作队伍建设是加强和改进新时代高校意识形态工作的组织保证, 是筑 牢高校意识形态工作前沿阵地的关键。本文从加强高校意识形态工作队伍主体布局、完善高 校意识形态工作队伍管理机制、提升高校意识形态工作队伍综合素质、增强高校网络意识形 态工作者队伍建设四个方面, 深入阐述加强和改进新时代高校意识形态工作队伍建设的有效 路径，从而为加强我国高校意识形态工作提供可行性建议。

关键词：高校，新时代，意识形态，队伍建设

\section{1. 前言}

任何一种思想的传播、宣传、灌输都是由特定的人员来实现。“任何国家要想增强自己的软 实力, 必须加强意识形态工作者队伍的建设。” [1]特别是在当前西方意识形态渗透加剧和国 内社会思潮多元多样的时代境遇下，我国意识形态安全面临严峻的压力与挑战。高校肩负着 宣传主流意识形态教育和培养合格社会主义建设者与接班人的重任, 同时又是意识形态领域 斗争的 “一线”。新时期、新形势对高校意识形态工作队伍建设提出更高更新的要求，切实 加强和改进新时代高校意识形态工作队伍建设, 对实现高校主流意识形态的主导权与话语权 具有重要现实意义。

\section{2. 加强高校意识形态工作队伍的主体布局}

习总书记在全国高校思想政治工作会议上指出，高校党政干部和共青团干部、思政课教师和 哲学社会科学课教师、辅导员和班主任是高校大学生思想政治教育的主体。青年马克思主义 者是青年学生群体的优秀代表, 在对周围学生发挥朋辈教育中起着不可替代的榜样示范和模 范引领作用，同样是高校大学生思想政治教育的重要组成部分。这四大主体在高校意识形态 工作中的地位和职能各有侧重、相互配合、有机统一，构成高校意识形态工作队伍的主体布 局，共同实现高校主流意识形态教育的目标和任务。 
1、强化高校领导体制, 落实党政干部和共青团干部的主体责任。学校党政干部和共青团干部 是高校意识形态工作的领导和管理队伍，要做到守土有责、守土负责、守土尽责。负责高校 意识形态工作的领导干部, 既包括学校分管高校意识形态工作的党委副书记, 学生工作部 (处) 从事高校思想政治工作的干部、院（系）党委（总支）负责高校思想政治教育工作的副书记， 也包括学校各级共青团干部。作为学校意识形态工作的领导者和管理者, 党政干部和共青团 干部要了解学校意识形态工作的总体规划, 能够坚决贯彻党的教育方针, 坚持党对高校的绝 对领导, 落实国家教育政策与法规。他们在学校的不同部门和基层组织工作, 对大学生思想 政治现状尤为熟悉, 能在明确职责、密切协作的基础上切实实现主流意识形态教育的目标。 2、思政课和哲学社会科学课教师是高校意识形态工作的重要队伍。思想政治理论课、哲学社 会科学课程的课堂教学是实现高校主流意识形态教育的主渠道。他们根据学科和课程的内容 和特点, 对学生进行思想理论的宣传和教育, 引导学生树立科学的世界观、人生观、价值观。 其主要职责表现在: 一是为人师表, 榜样示范。以高度负责的态度, 率先垂范、言传身教, 以良好的思想、道德、品质和人格给大学生以潜移默化的影响, 使学生在对先进思想品德自 觉奉行、信仰的个性化行动中受到感染和影响。二是挖掘价值, 渗透教育。专业教师应当深 入挖掘学科中的思想政治教育价值, 自觉地将思想政治教育融入大学生专业学习的各个环节, 渗透到教学、科研和社会服务各个方面, 在传授专业知识过程中加强主流意识形态教育, 使 学生在学习科学文化知识的同时，自觉加强思想道德修养，提高自身思想政治觉悟。

3、辅导员、班主任是高校主流意识宣传教育的骨干力量。辅导员按照学校、院系党委的部署, 有针对性地开展大学生思想政治教育活动, 班主任负有在思想、学习和生活等方面指导学生 的职责。辅导员、班主任是高校教师队伍和管理队伍的重要组成部分，是大学生日常思想政 治教育主阵地上的基层指挥员，工作在高校意识形态工作的第一线，是做好大学生日常思想 政治教育和管理的骨干队伍, 对大学生的成长起着至关重要的作用。改革开放以来, 随着高 校思想政治教育面临的形势和目标的不断变化, 辅导员、班主任的职能也不断调整、完善, 逐步形成比较系统的职能体系。

4、青年马克思主义者在高校主流意识形态教育中发挥独特优势。青年，既是高校主流意识形 态主导权建设的主体，同时也是高校主流意识形态教育的对象。青年马克思主义者是青年学 生的优秀代表, 他们具有坚定的马克思主义信仰, 有较高的思想觉悟和党性修养, 又身处学 生周围, 在同辈群体中发挥着榜样示范、思想引领的独特优势, 是高校意识形态工作队伍的 新兴主体。为此, 发挥高校马克思主义理论学科优势, 培养和造就一大批青年马克思主义者。 通过科学的马克思主义思想体系武装青年学生, 使青年学生对马克思主义的认识从感性认识 升华到理性认识，使其具备基本的马克思主义理论储备与素养。

\section{3. 完善高校意识形态工作队伍的管理机制}

1、做好队伍选拔工作。高校意识形态工作队伍的选拔, 既要拓宽选拔视野、又要高标准高要 求严格选拔。搞好选拔工作，通过科学合理的方式，发现和挑选优秀人才，择优任用到高校 意识形态工作岗位上, 是高校意识形态队伍建设的前提和基础。在选拔过程中, 要坚持德才 兼备的标准。“德”，即要把具备较高的思想政治素质，在思想上、政治上自觉与党中央保 持一致，有志献身于高校思想政治教育工作的人才选拔出来，以保证队伍的革命化。“才”， 即要把具备从事高校意识形态宣传工作所需要的相关知识和专业技能的人才选拔出来，以实 现高校意识形态工作队伍的知识化和专业化。

2、抓好队伍教育培训。高校要结合新形势发展的实际, 更新意识形态工作队伍的教育观念, 及时开展政治理论学习和技能培训。通过组织培训班、举办专题讲座及研讨会等多种形式的 活动, 提高高校意识形态工作者的政策理论水平和工作能力, 推动主流意识形态理论的创新 和发展, 努力使马克思主义意识形态积极引领学生发展的需要, 并对意识形态领域中出现的 新情况、新问题做出科学的解释和判断, 为维护我国主流意识形态安全服务, 这支队伍的建 
设成就, 与高校主流意识形态主导权、话语权的实现程度密切相关。因此, 通过教育培训, 在新世纪新阶段培育和造就一批高水平的高校意识形态工作者队伍十分重要。

3、强化队伍实践锻炼。“实践出真知”, 实践对高校意识形态工作者素质的提高具有决定性 作用。意识形态工作者的许多知识和能力只有在实践中才能获知, 并得到锻炼和提高。因此, 高校意识形态工作者要在坚持正确理论的指导下, 加强实践锻炼。高校要组织意识形态工作 者参加社会实践, 通过深入学生基层及省内外兄弟院校, 了解国情, 了解现代高等教育中出 现的新情况、新问题, 学习新时期思想政治工作的好做法。广大思想政治教育干部要勇于实 践, 善于实践, 运用所学的知识, 结合自己的业务工作, 从实践中总结经验, 使其条理化、 系统化、理论化，从而提高自己的工作能力和工作效率。

4、健全激励与考核机制。建立健全激励与考核机制是有效提高高校意识形态工作队伍工作热 情、强化责任意识的重要举措, 是高校意识形态工作队伍管理中不可或缺的一个重要环节。 为此, 要营造良好的竞争氛围, 不断强化竞争观念, 采取多种形式和途径使高校意识形态工 作队伍在竞争中强化责任意识; 要创造多种激励形式, 如竞争上岗、职称评定、提高工资待 遇等等。此外, 要建立公平公正、动态立体的高校意识形态工作队伍考核机制, 完善高校意 识形态工作队伍的考核标准、考核程序和步骤, 以此不断提高高校意识形态工作者的能力水 平。

\section{4. 提升高校意识形态工作队伍的综合素质}

“主流意识形态宣传能否真正为群众所接受、所认同, 很大程度上取决于意识形态工作队伍 的综合水平。” [2]面对新形势发展的客观要求, 面对新阶段所肩负的艰巨任务, 高校宣传思 想部门要做到守土有责、守土负责、守土尽责, [3] 意识形态工作队伍素质还需要进一步提高。

1、意识形态工作者既要坚定地信仰马克思主义, 又要精通马克思主义。意识形态工作者要坚 定马克思主义信仰, 坚信中国特色社会主义理论体系。只有真信, 才能激发理论研究和宣传 的兴趣和热情, 这也是高校意识形态工作者的基本素养。此外, 要加强学习, 通过学习掌握 马克思主义基本原理, 提高运用马克思主义的立场、观点和方法分析矛盾、解决矛盾的能力, 深入社会实践, 注重调查研究, 了解社会上的热点问题, 科学分析新形势下做好理论阐释和 宣传普及工作, 在重大的政治和理论问题上, 立场坚定, 敢于同各种反马克思主义错误思潮 进行对话、交锋和斗争, 增强马克思主义意识形态理论的引领力。

2、意识形态工作者要学会创新话语表达。高校意识形态工作者要从内容、形式和语言等多方 面充分考虑到受众群体的需求, 通过创新话语表达方式, 将晦涩难懂的理论以通俗易懂的语 言表达出来, 优化话语传播内容, 用富有生活气息和民族气息的语言和文字消除马克思主义 理论和大众之间的心理距离, 增强马克思主义意识形态的亲和力, 使马克思主义真正走入大 众生活。列宁曾指出, “要善于用身边发生的小事来说明共产主义的信念。” [4] 高校思想政 治宣传的语言表达, 要避免生硬呆板, 杜绝口号式、标语式的空话、套话、大话。用简洁明 快、通俗易懂的话语表达方式来进行思想政治教育工作。

3、意识形态工作者要学会运用多种舆论传播载体来宣传马克思主义。一定的文化和思想的传 播不仅需要大量合格的传播者, 更需要多样的载体。传播理论认为: “信息传播量愈多, 思 想认同愈高”。[5]因此, 通过形式多样的传播载体来增强信息的传播广度, 是促进文化认同 的重要方式。为此, 高校意识形态工作者要完善马克思主义网络宣传体系, 丰富网络信息平 台建设, 通过设立网站、公众号等, 多渠道开展思想宣传教育, 努力使主流意识形态占领网 络阵地。在网络阵地中要建立众多的马克思主义理论宣传教育网页, 扩大马克思主义意识形 态在学生群众中的影响力。此外, 不断创新网络平台的内容和形式, 扩大受众层面, 贴近学 生需求, 提高人性化服务, 增强平台影响力。 


\section{5. 增强高校网络意识形态工作者队伍建设}

在大数据时代, 我国意识形态安全面临新的严峻形势。网络空间逐渐成为意识形态渗透的主 战场, 而活跃在网络空间中的青年学生成为西方国家对我国进行意识形态渗透的主要对象, 高校意识形态工作面临更加艰巨的挑战。为此, 高校要抓住机遇、迎接挑战, 加快建设一批 高素质的高校网络意识形态工作者队伍，巩固高校主流意识形态的主导地位。

高校网络意识形态工作者队伍既要熟悉马克思主义基本理论, 又要熟练掌握互联网技术。为 打造这样一支队伍, 要通过专门技术培训, 提高网络意识形态工作者的互联网操作技术, 掌 握熟练的计算机操作能力, 提升在网络空间宣传马克思主义意识形态的水平, 增强与各种错 误思潮进行交锋和斗争的本领。通过加强网络平台建设, 使互联网成为进行高校大学生思想 政治教育的前沿阵地。一方面, 要建设一批适应大学生个性特点、喜闻乐见的宣传网页和交 互平台, 通过校内网络阵地建设, 积极宣传马克思主义意识形态, 壮大主流意识形态與论, 引领青年学生健康成长。另一方面, 要在宣传的内容和形式上与时俱进、不断创新, 使用贴 近学生的、通俗易懂的、具有时代气息的网络语言，提高高校主流意识形态的亲和力。 此外, 要在网络空间中积极培育宣传高校主流意识形态的 “意见领袖”。在网络群体意见形 成过程中有一部分人的意见对群体影响较大, 能在一定程度上左右群体意识的方向, 这部分 人称为 “意见领袖” ， “意见领袖” 往往是长期从事某项研究的行家里手，或是善于分析推 理的思考者, 或者是了解内幕的参与者, 他们发表的观点感染力大, 有很强的说服力。通过 这样一支队伍的自觉地宣传高校主流意识形态教育, 阐述对社会热点问题的认识、发表对敏 感事件的观点, 对错误思想言论的批判等一系列舆论引导行为, 实现对高校主流意识形态的 正确引领。

\section{References}

[1]. Zhang Goofing, some thoughts on the "discourse power" [J]. Marxist Studies, 2009 (3): 45.

[2]. Sheng Xinyang, the socialist core value system to lead the propaganda and education path of social thoughts [J]. Century Bridge, 2012 (17): 5.

[3]. "Thinking about the overall situation, grasping the general trend and focusing on major issues, and striving to do better propaganda and ideological work" [N], Ganging Daily, and August 21, 2013.

[4]. Selected Works of Lenin, Volume 1 [M]. Beijing: People's Publishing House, 1955: 364.

[5]. [[United States] Steven Little John. Communication theory [M]. Translated by Chen Deming, Beijing: China Social Sciences Press, 1999:97. 